\title{
In-Hospital Outcomes of Percutaneous Coronary Interventions in Type C Lesions: CENIC Registry
}

\author{
Raphael Kazuo Osugue, Vinicius Esteves, Arthur Pipolo, Daniel Silva Ramos, Cristiano Abdel Massih, \\ Ulises A. Solorzono, Galo A. Maldonado, César Augusto Esteves
}

\begin{abstract}
Background: Type C coronary lesions represent a complex angiographic scenario, although they are rather common in the daily clinical practice of percutaneous coronary intervention (PCI). This article aimed to report the Brazilian clinical practice outcomes of $\mathrm{PCls}$ performed in patients with type $\mathrm{C}$ lesions. Methods: This was a retrospective study with information obtained from the electronic database of the Central Nacional de Intervenções Cardiovasculares (National Cardiovascular Intervention Centre - CENIC) of the Sociedade Brasileira de Hemodinâmica e Cardiologia Intervencionista (Brazilian Society of Haemodynamics and Interventional Cardiology - $\mathrm{SBHCl}$, which gathers information on $\mathrm{PCl}$ procedures in a dedicated database, entered by volunteer physicians who are members of several Brazilian institutions. Results: Between January, 2010 and December, 2011, 1,693 patients with type C lesions were registered in CENIC. Most patients were males $(68 \%)$, with a mean age of $63 \pm 26.3$ years, $40.9 \%$ were diabetic, and $45.4 \%$ had acute coronary syndromes. Procedural success was achieved in $95.6 \%$ of the cases, mortality was $2.1 \%$, acute myocardial infarction was observed in $5 \%$, and repeat target-lesion revascularisation was $0.5 \%$ in patients during the hospitalisation. Conclusions: $\mathrm{PCl}$ in type $\mathrm{C}$ lesions presented high success and low complication rates in a selected population from the CENIC registry. The former morphological classification of the lesions, still used in the registry, does not properly stratify the outcomes of PCls. It is urgently necessary to update the data collection form and related measures in order to improve the quality control of the registry.
\end{abstract}

DESCRIPTORS: Angioplasty. Stents. Coronary disease. Registries.

Hospital Beneficência Portuguesa de São Paulo - São Paulo, SP, Brazil. Correspondence to: Raphael Kazuo Osugue. Rua Maestro Cardim, 769 - Bela Vista - São Paulo, SP, Brazil - CEP 01323-900

E-mail: rosugue@yahoo.com.br

Received on: 1/3/2012 • Accepted on: 3/13/012
RESUMO

Resultados Hospitalares das Intervenções Coronárias Percutâneas em Lesões Tipo C: Registro CENIC

Introdução: Lesões coronárias tipo C representam um cenário angiográfico complexo embora bastante comum na prática clínica diária da intervenção coronária percutânea (ICP). Nosso objetivo foi apresentar os resultados da prática clínica nacional das ICPs realizadas em pacientes com lesões tipo C. Métodos: Estudo retrospectivo, com informações obtidas a partir dos dados inseridos no registro eletrônico da Central Nacional de Intervenções Cardiovasculares (CENIC) da Sociedade Brasileira de Hemodinâmica e Cardiologia Intervencionista ( $\mathrm{SBHCl}$ ), e que agrega informações sobre procedimentos das ICPs reunidos em um banco de dados dedicado, com preenchimento voluntário por médicos associados de várias instituições brasileiras. Resultados: Entre janeiro de 2010 e dezembro de 2011, foram incluídos 1.693 pacientes com lesões tipo C devidamente cadastrados na CENIC. Predominaram pacientes do sexo masculino (68\%), com média de idade de $63 \pm$ 26,3 anos, $40,9 \%$ eram diabéticos e $45,4 \%$ apresentaram quadros clínicos instáveis. Sucesso do procedimento foi alcançado em $95,6 \%$ dos casos, a mortalidade foi de $2,1 \%$, infarto agudo do miocárdio ocorreu em $5 \%$ e revascularização da lesão-alvo ocorreu em $0,5 \%$ dos pacientes na fase hospitalar. Conclusões: As ICPs em lesões tipo $C$ do registro CENIC apresentaram altas taxas de sucesso e baixas taxas de complicação, numa amostra da população relativamente selecionada. A antiga classificação morfológica das lesões, ainda adotada no registro, não estratifica adequadamente os resultados da ICP na era contemporânea. A atualização da ficha de coleta dos dados e medidas que intensifiquem o controle de qualidade do registro são urgentes e necessárias.

DESCRITORES: Angioplastia. Stents. Doença das coronárias. Sistema de Registros. 
there was a greater preponderance of immediate results after the procedure, with lower rates of acute occlusion, ${ }^{3-7}$ especially in more complex anatomic lesions. As a consequence of better results and new techniques, the need to reformulate this classification arose as did the need for new definitions, reflecting the experience acquired in procedures of greater complexity. ${ }^{8}$

The aim of the present study was to analyse the profile and contemporary in-hospital results of patients undergoing $\mathrm{PCl}$ of type $\mathrm{C}$ lesions recorded in the database of the Central Nacional de Intervenções Cardiovasculares (National Cardiovascular Intervention Centre-CENIC) between 2010 and 2011.

\section{METHODS}

This was a retrospective study with information obtained from the CENIC electronic record, created in 1991 by the Sociedade Brasileira de Hemodinâmica e Cardiologia Intensiva (Brazilian Society of Haemodynamics and Interventional Cardiology - SBHCI), which archives information on $\mathrm{PCl}$ in a dedicated database voluntarily recorded by associated physicians from several Brazilian institutions.

For this study, all procedures involving type $\mathrm{C}$ lesions recorded between January, 2010 and December, 2011 were included. The definition of type $C$ lesion was established from an American guideline, designating lesions as having a high risk of complications if they present at least one of the following characteristics: length of lesion $>20 \mathrm{~mm}$; excessive tortuosity of the proximal segment; target segment with extreme angulation (> 90 degrees); chronic occlusion ( $>$ three months); inability to protect larger lateral branches; or degenerated venous grafts. The data collected and used in this study were related to clinical, angiographic, and procedural characteristics, including in-hospital complications. Procedural success or failure definitions and in-hospital complications (death, acute myocardial infarction, stroke, and target-vessel revascularisation) included those commonly used by clinicians when completed the forms related to each procedure in the CENIC database.

Continuous variables were expressed as mean \pm standard deviation, while categorical variables were expressed as absolute numbers and percentages.

\section{RESULTS}

In this study, 1,693 patients from the CENIC electronic address (www.sbhci.org.br) for the previously mentioned study period were evaluated. Table 1 presents the clinical characteristics of the patients. Most patients were male $(68 \%)$, with a mean age of $63 \pm 26.3$ years. High clinical complexity with an elevated incidence of diabetes $(40.9 \%)$, prior acute myocardial infarction $(20.9 \%)$, and prior revascularisation procedures, whether surgical $(16.3 \%$ ) or percutaneous $(18.4 \%)$, were observed.
Regarding the reason for the intervention, $54.6 \%$ were stable; of these, $34.7 \%$ had stable angina, and $19.9 \%$ were asymptomatic. ST-elevation myocardial infarction was observed in $16.4 \%$ of patients, and acute coronary syndrome without ST-elevation was observed in $29 \%$. In this last subgroup, risk stratification according to the TIMI score evidenced that a majority of patients (57.3\%) were classified as high risk, $24.5 \%$ as moderate risk, and $18.2 \%$ as low risk.

In patients with ST-elevation myocardial infarction, $77.1 \%$ were classified as Killip I, $11.8 \%$ as Killip II, and $4.5 \%$ as Killip III. In addition, $6.6 \%$ were in cardiogenic shock. Primary angioplasty was performed in $69.1 \%$ of patients, with a door-to-balloon time of $65 \pm 110$ minutes. Elective angioplasty in the same subgroup was performed in $19.8 \%$ of patients, with a mean delay for the procedure of $16 \pm 11$ days. Rescue angioplasty was performed in $10.8 \%$ of the cases, with facilitated angioplasty in only $0.3 \%$ of patients. The mean in-hospital length of stay was $2.5 \pm 5$ days.

The femoral approach was used in $95.6 \%$ of cases, and the radial approach was used for the remainder (14.7\%). Angiographic characteristics observed in this population demonstrated a predominance of patients

TABLE 1 Clinical Characteristics

\begin{tabular}{lc}
\hline Variables & $\mathbf{n}=\mathbf{1 , 6 9 3}$ \\
\hline Male gender, \% & 68 \\
Risk factors, \% & \\
Diabetes mellitus & 40.9 \\
$\quad$ On insulin & 6.1 \\
Hypertension & 81.9 \\
Smoking & 26.9 \\
Dyspilidaemia & 49.7 \\
Family history of CAD, \% & 19.5 \\
Prior AMI & 20.9 \\
Prior CABG & 16.3 \\
Prior PCl & 18.4 \\
Clinical presentation, \% & \\
Asymptomatic & 19.9 \\
Stable angina & 34.7 \\
Non-ST-elevation myocardial & 29 \\
infarction & \\
ST-elevation myocardial infarction & 16.4 \\
\hline AMl = acute myocardial infarction; CAD = coronary artery \\
disease; $\mathrm{n}=$ number of patients; PCI = percutaneous coronary \\
intervention; CABG = coronary artery bypass graft. \\
\hline
\end{tabular}


with one vessel disease (35.8\%), and the vessels treated most often included the right coronary artery $(33.2 \%)$ and left anterior descending artery $(31.5 \%)$. Among the morphologic findings of type C lesions, calcification and length $>20 \mathrm{~mm}$ were most often reported, with an incidence of $43.3 \%$ and $21.3 \%$, respectively. The mean stenosis of the lesions was $87.1 \pm 13.2 \%$.

Procedural success was observed in $95.6 \%$ of the patients. Reasons for procedural failure included inability to cross the lesion $(1.9 \%)$, crossing the lesion but without successful dilation $(1.6 \%)$, and acute occlusion $(0.9 \%)$.

Table 3 presents the in-hospital clinical results. All-cause mortality was $2.1 \%$, of whom $77.1 \%$ were due to cardiac causes. Acute myocardial infarction was observed in $5 \%$ of patients, of whom $77.4 \%$ did

TABLE 2

Angiographic Characteristics of the Procedure

\begin{tabular}{|c|c|}
\hline Variables & $\begin{array}{c}n=1,693 \\
\text { patients/ } \\
2,829 \text { lesions }\end{array}$ \\
\hline \multicolumn{2}{|l|}{ Number of vessels involved, \% } \\
\hline One & 35.8 \\
\hline Two & 25 \\
\hline Three & 12.2 \\
\hline LMCA & 2.5 \\
\hline \multicolumn{2}{|l|}{ Vessels treated, \% } \\
\hline LAD & 31.5 \\
\hline LCx & 13.6 \\
\hline RCA & 33.2 \\
\hline LMCA & 1 \\
\hline Saphenous vein grafts & 8.4 \\
\hline Calcified lesions, \% & 43.3 \\
\hline Lesions $>20 \mathrm{~mm}, \%$ & 21.3 \\
\hline Lesions with thrombus, \% & 12.2 \\
\hline Occluded lesions, \% & 23.8 \\
\hline Successful procedure, $\%$ & 95.6 \\
\hline \multicolumn{2}{|l|}{ Reasons for failure, $\%$} \\
\hline Did not cross the lesion & 1.9 \\
\hline $\begin{array}{l}\text { Crossed the lesion but failed } \\
\text { to dilate }\end{array}$ & 1.6 \\
\hline Acute occlusion & 0.9 \\
\hline
\end{tabular}

not show new $\mathrm{Q}$ waves on post-procedure electrocardiograms. No episodes of ischaemic or haemorrhagic stroke were observed. Target-vessel acute or subacute occlusion was identified in $26(1.53 \%)$ patients, of whom $18(69.2 \%)$ were maintained on clinical treatment without mechanical intervention, seven $(26.9 \%)$ returned to the cath laboratory to undergo repeat angioplasty, and one $(3.85 \%)$ was referred for elective surgery. Major and minor vascular complications were observed in six $(0.4 \%)$ patients, and $28(1.7 \%)$ patients developed contrast-induced nephropathy.

\section{DISCUSSION}

The classification of angiographic lesions was established in 1988 by a committee of the American College of Cardiology (ACC) and the American Heart Association (AHA), and was immediately validated by several studies. ${ }^{2-9}$ The objective of this classification was to stratify angiographic lesions according to their complexity and, thereby, estimate the success and risk of complications from angioplasties.

Initially, the division of lesions into type A (low complication rate and success $>85 \%$ ), type B (moderate complication risk and success between $60 \%$ and $85 \%$ ), and type $\mathrm{C}$ (high complication risk and success $<60 \%$ ) was proposed. Subsequently, Ellis et al. ${ }^{1}$ recommended that type $B$ lesions should be subdivided if they presented one (B1) or more (B2) severity criteria.
TABLE 3 In-hospital Clinical Results

\begin{tabular}{lc}
\hline Variables & $\mathbf{n}=\mathbf{1 , 6 9 3}$ \\
\hline Mortality, n (\%) & $35(2.1)$ \\
Cardiac & $27(77.1)$ \\
Non-cardiac & $6(17.1)$ \\
Not reported & $2(5.7)$ \\
Acute myocardial infarction, n (\%) & $84(5)$ \\
with Q wave & $19(22.6)$ \\
without Q wave & $65(77.4)$ \\
Stroke (ischaemic/haemorrhagic), n (\%) & 0 \\
Target-lesion revascularisation, n (\%) & $8(0.5)$ \\
Vascular complications, $\mathrm{n}(\%)$ & $6(0.4)$ \\
Minor & $3(0.2)$ \\
Major & $3(0.2)$ \\
Contrast-induced nephropathy, n (\%) & $28(1.7)$ \\
\hline $\mathrm{n}=$ number of patients. & \\
\hline
\end{tabular}


Notably, the first classification was based on results of procedures performed almost exclusively with balloon-catheters, which have greater complication and failure rates. With the technological evolution of the materials used in the procedures, in addition to the expressive collaboration of adjunct pharmacology, this classification needs to be re-evaluated.

Wilensky et al. ${ }^{10}$ analysed 2,839 patients in the National Heart, Lung, and Blood Institute Dynamic Registry with complex lesions, defined as lesions with evidence of thrombus, calcification, bifurcation, or in the ostium; and they compared these patients with 1,720 patients who presented with non-complex lesions. Complex lesions were associated with higher rates of dissection, distal embolisation, obstruction of secondary branches, and persistent reduction in coronary flow. Patients with complex lesions had a lower rate of success $(93.8 \%$ vs. $97.3 \% ; \mathrm{P}<0.001)$ and a greater rate of in hospital death $(2 \%$ vs. $0.6 \% ; \mathrm{P}<0.001)$, death/acute myocardial infarction (5.2\% vs. $2.4 \%$ ), and death/myocardial infarction/coronary artery bypass graft surgery (6.5\% vs. $2.9 \%$ ).

Despite the limitations of the present study, which include underreporting of cases and missing data due to voluntary contributions, it is clear that the old classification of A, B1, B2, and C types, which is still used in the CENIC registry, does not adequately stratify the success and complication rates of the procedure.

In fact, a new classification of lesions proposed by the Society for Cardiac Angiography and Intervention (SCAI), a simplified version of the 1988 ACC/ AHA classification (Table 4), has demonstrated greater discriminatory power for success and complications. ${ }^{11}$ This classification system requires only two discriminations (C/non-C lesion and occluded/non-occluded lesion) that can be reliably and reproducibly distinguished by experienced professionals.

Thus, a reformulation of variables and their definitions used in the clinical and angiographic characterisation of patients and interventions, the inclusion of all procedures performed in a pre-specified period, an increase in the number of institutions to better reflect reality, and the collection of data are necessary measures to update the CENIC registry.

In a recent editorial, Mattos ${ }^{12}$ suggested that revitalisation measures should be applied to bring more strength to the registry, with periodic meetings of participating centres in order to maintain a united, active, and stimulated group. In addition, Mattos ${ }^{12}$ recommended independent monitoring of the data and increasing the centres of the collected data to encompass late patient follow-up.

\section{CONCLUSIONS}

$\mathrm{PCl}$ of type $\mathrm{C}$ lesions, as categorised by the CENIC registry, presented high success rates and low complication rates in a relatively selective population. The old
TABLE 4 Classification of Lesions According to SCAI ${ }^{11}$

Type I Lesion

(1) Does not satisfy criteria for a type C lesion

(2) Non-occluded

Type II Lesion

(1) Has one of the criteria for type C lesion Diffuse (length $>20 \mathrm{~mm}$ )

Excessive tortuosity of the proximal segment Extremely angulated segments (> 90 degrees) Inability to protect major secondary branches Venous grafts with friable lesions

(2) Non-occluded

Type III Lesion

(1) Does not satisfy the criteria for a type C lesion

(2) Occluded

Type IV Lesion

(1) Has one of the criteria for a type C lesion

Diffuse (extension $>20 \mathrm{~mm}$ )

Excessive tortuosity of the proximal segment

Extremely angulated segments (> 90 degrees)

Inability to protect major secondary branches

Venous grafts with friable lesions

Occlusion > three months

(2) Occluded

morphologic classification, still used by the registry, is no longer adequate for stratifying $\mathrm{PCl}$ results. Updating the data collection form and adopting measures that increase the quality control of the registry are urgent and necessary.

\section{CONFLICTS OF INTEREST}

The authors declare no conflicts of interest.

\section{REFERENCES}

1. Ellis SG, Vandormael MG, Cowley MJ, DiSciascio G, Deligonul U, Topol EJ, et al. Coronary morphologic and clinical determinants of procedural outcome with angioplasty for multivessel coronary disease: implications for patient selection. Multivessel Angioplasty Prognosis Study Group. Circulation. 1990;82(4):1193-202.

2. American College of Cardiology; American Heart Association Task Force, Subcommittee on Percutaneous Transluminal Coronary Angioplaty Guidelines for percutanous transluminal coronary angioplasty. A report of the American College of Cardiology/ American Heart Association Task Force (Subcommittee on Percutaneous Transluminal Coronary Angioplasty). J Am Coll Cardiol. 1988;12(2):529-45. 
3. Appelman YE, Piek JJ, Redekop WK, de Feyter PJ, Koolen JJ, David GK, et al. Clinical events following excimer laser angioplasty or balloon angioplasty for complex coronary lesions: subanalysis of a randomised trial. Heart. 1998;79(1):34-8.

4. Tebet MA, Serpa R, Andrade PB, Labrunie A, Mattos LA, Mangione JA. Análise comparativa dos eventos adversos imediatos após o implante de stents farmacológicos ou convencionais: resultados imediatos do Registro Brasileiro CENIC. Rev Bras Cardiol Invasiva. 2006;14(3):290-5.

5. Devito FS, Marin-Neto JA, Mattos LA. Análise comparativa da intervenção coronária percutânea com stents farmacológicos versus stents não-farmacológicos na vigência de infarto do miocárdio com supradesnivelamento do segmento ST: dados do Registro Brasileiro CENIC. Rev Bras Cardiol Invasiva. 2008; 16(4):456-62.

6. Li Y, Li CX, Wang HC, Xu B, Fang WY, Ge JB, et al. Efficacy and safety of Firebird sirolimus-eluting stent in treatment of complex coronary lesions in Chinese patients: one-year clinical and eight-month angiographic outcomes from the FIREMAN registry. Chin Med J (Engl). 2011;124(6):817-24.

7. Cohen DJ, Bakhai A, Shi C, Githiora L, Lavelle T, Berezin RH, et al. Cost-effectiveness of sirolimus-eluting stents for treatment of complex coronary stenoses results from the Sirolimus-Eluting Balloon Expandable Stent in the Treatment of Patients With De Novo Native Coronary Artery Lesions (SIRIUS) Trial. Circulation. 2004;110(5):508-14.
8. Krone RJ, Shaw RE, Klein LW, Block PC, Anderson HV Weintraub WS, et al. Evaluation of the American College of Cardiology/American Heart Association and the Society for Coronary Angiography and Interventions lesion classification system in the current stent era of coronary interventions (from the ACC-National Cardiovascular Data Registry). Am J Cardiol. 2003;92(4):389-94

9. Ellis SG, Roubin GS, King SB $3^{\text {rd }}$, Douglas JS Jr, Weintraub WS Thomas RG, et al. Angiographic and clinical predictors of acute closure after native vessel coronary angioplasty. Circulation. 1988;77(2):372-9.

10. Wilensky RL, Selzer F, Johnston J, Laskey WK, Klugherz BD, Block $\mathrm{P}$ et al. Relation of percutaneous coronary intervention of complex lesions to clinical outcomes (from the NHLBI Dynamic Registry). Am J Cardiol. 2002;90(3):216-21.

11. Levine GN, Bates ER, Blankenship JC, Bailey SR, Bittl JA, Cercek B, et al. 2011 ACCF/AHA/SCAI Guideline for Percutaneous Coronary Intervention: a report of the American College of Cardiology Foundation/American Heart Association Task Force on Practice Guidelines and the Society for Cardiovascular Angiography and Interventions. Circulation. 2011;124(23):e574-651.

12. Mattos LA. Registro CENIC-SBHCl: envidar novas ideias para renovar um projeto perene [editorial]. Rev Bras Cardiol Invasiva. $2011 ; 19(2): 115-7$. 